\title{
Inventory of the termitofauna and fluctuation associated with forest restoration of the atlantic forest
}

The objective of this work was to evaluate the forest restoration of the basin of Guapiaçu river in Cachoeiras de Macacu, RJ, using the families of Termites as tools for environmental assessment. We analyzed the population fluctuation and feeding guilds of the families of the Termites: Kalotermitidae, Rhinotermitidae and Termitidae. Six sampling points were arranged along Guapiaçu river, five points being inferred in reforestations carrieds out in the basin and a point in a regeneration control area. Quantitative and qualitative surveys followed standard protocols and the samples were obtained directly, without baits. Thirty taxons were identified and the family Termitidae was the most frequent. The termitofauna of the amostral control point P06 was the richest. From the frequencies of occurrences of the species related to their trophic guild, an ecological evaluation table of the environments was proposed, where the P05 area rich in climactic plant species was the one that presented the greatest similarity to the natural regeneration area P06. The majority of the species was classified as xilophagous.

Palavras-chave: Applied Entomology; Conservation of Natural Areas; Ecology of Forest Ecosystems.

\section{Inventario de la termitofauna y fluctuación asociada a la restauración forestal en la mata atlántica}

El objetivo de este trabajo fue evaluar la restauración forestal de la cuenca del río Guapiaçu, en Cachoeiras de Macacu, RJ, utilizando las familias de termitas como herramientas de evaluación ambiental. Analizamos la fluctuación poblacional y los gremios de alimentación de las familias de las termitas: Kalotermitidae Rhinotermitidae y Termitidae. Seis puntos muestrales fueron dispuestos a lo largo del río Guapiaçu, cinco puntos siendo inferidos en reforestaciones realizadas en la cuenca y un punto en un área de control de regeneración. Los levantamientos cuantitativos y cualitativos siguieron los protocolos estándar y las muestras fueron obtenidas directamente, sin cebos. Se identificaron treinta taxones y la familia Termitidae fue la más frecuente. La termitofauna del punto de control de la muestra P06 fue la más rica. A partir de las frecuencias de las ocurrencias de las especies relacionadas a su gremio trófico, se propuso una tabla de evaluación ecológica de los ambientes, donde el área de P05 rica en especies de plantas climácicas fue la que presentó mayor similitud con el área de regeneración natural P06.

Keywords: Entomología Aplicada; Conservación de Áreas Naturales; Ecología de Ecosistemas Forestales.

Topic: Ciências Florestais

Reviewed anonymously in the process of blind peer
Received: 05/04/2019

Approved: 10/05/2019
Cleber Vinicius Vitorio da Silva id

Universidade Federal Rural do Rio de Janeiro, Brasil http://lattes.cnpq.br/4275890458575782

http://orcid.org/0000-0001-8337-9615

clebervitorio88@gmail.com

Acácio Geraldo de Carvalho (ic

Universidade Federal Rural do Rio de Janeiro, Brasil http://lattes.cnpq.br/6260575742015817

http://orcid.org/0000-0002-0935-7773

acacio@ufri.br

Josimar Ribeiro de Almeida (iD

Universidade do Estado do Rio de Janeiro, Brasil

http://lattes.cnpq.br/3215586187698472

http://orcid.org/0000-0001-5993-0665

almeida@poli.ufrj.br
Carlos Eduardo Silva (ID)

Universidade Tiradentes, Brasil

http://lattes.cnpq.br/3700554054159220

http://orcid.org/0000-0001-8358-0263

carlos.eduardo@cbpciencia.com.br
Referencing this:

SILVA, C. V. V.; CARVALHO, A. G.; ALMEIDA, J. R.; SILVA, C. E.. Inventory of the termitofauna and fluctuation associated with forest restoration of the atlantic forest. Agriculturae, v.1, n.1, p.1-12, 2019 DOI: http://doi.org/10.6008/CBPC2674-645X.2019.001.0001 


\section{INTRODUCTION}

The termites, belong to the order Blattodea and have a cosmopolitan distribution, occurring both in places of temperate and tropical areas, with a large diversity of species in the neotropical region, as happens with several orders of insects (CABRERA et al., 2009; REIS et al., 2009; KRISHNA et al., 2013). There are more than 3,300 species described, distributed in nine families: Mastotermitidae, Archotermopsidae, Hodotermitidae, Stolotermitidae, Stylotermitidae, Kalotermitidae, Rhinotermitidae, Serritermitidae and Termitidae (ROCHA et al., 2012; KRISHNA et al., 2013). In Brazil, there were approximately 300 species contained in four families: Kalotermitidae, Rhinotermitidae, Serritermitidae and Termitidae. This diversity is certainly underestimated since the data for many regions of Brazil, mainly the North and Northeast, is scarce. Most of the data come from data collection in the Atlantic Forest and the Cerrado Biomes, both acknowledge as hot spots (CONSTANTINO, 1998, 2002).

The insects can be used to determinate the anthropic interference in various ecosystems, in biomonitoring. Therefore, there has been an interest to obtain information about their dynamics, thus gaining insight about the ecosystem quality (CRISTO et al., 2018).

The termitofauna is globally recognized for its ecosystem engineering services, however the termite fauna of the neotropical region has been poorly studied, when compared to the termites in the regions of the old world, as, the Eastern and African regions. There are few studies in the literature about the termites of the Atlantic Forest. Even smaller is the amount of studies addressing auto-ecology and sin-ecology of these species. Thus, Bandeira et al. (1998) mapped the termitofauna in forest fragments of the city João Pessoa, Paraiba state. They found that $65 \%$ to $88 \%$ of the species they had identified were not known by the scientific community, which enriches the literature about the biome. Brandão (1998) mapped the termitofauna at the Reserva Florestal de Linhares, Espirito Santo state and verified a decrease in richness with the change of floristic and pedological structure in the areas of study. Termites are ecologically relevant to tropical ecosystems, especially when considered the changes that they cause to the environment, in particular the forest ecosystem, from landscape changes to changes in physical and chemical properties of the soil, effects in the process of decomposition, nutrient cycling, among others (KRISHNA et al., 2013).

Several authors have made various attempts to classify the species of termites in trophic guilds, according to their use of resources (ROCHA et al., 2012; WOOD, 1977; CONSTANTINO, 1992; EGGLETON et al., 1995). As the biology of many species of termites is still unknown, there are difficulties to classify them in different guilds. Comparing diversity and richness of termites between primary forest areas and areas where there was a mischaracterization of the original vegetation were performed by Eggleton et al. (1995), with sampling techniques and different results. In this work the authors observed a dramatic, difference between an area of primary forest and pasture. As expected, the fauna of the primary forest was the most diverse and complex.

In the state of Rio de Janeiro, the forest restauration actions carried out in the basin of Guapiaçu river in Cachoeiras de Macacu (AZEVEDO et al., 2018), the headwaters of the river is located in a preserved area, 
at 1,200 $\mathrm{m}$ altitude, in the midst of the hilly slopes of the Serra do Mar (AZEVEDO et al., 2018). The basin has a territorial extension of $573.54 \mathrm{~km}^{2}$, having as main soil covered with Dense Ombrophilous Forest (AZEVEDO et al., 2018), very diverse, forming three strata: emerging with canopy trees, reaching about $45 \mathrm{~m}$ of height, on the main canopy of 5 to $10 \mathrm{~m}$ and smaller trees their shadows (AZEVEDO et al., 2018). Ecosystems such as altitude fields, swamps, lakes and rivers were also observed in the basin. The main river of the basin, the river Guapiaçu, in the past, used to be navigable river. According to Azevedo et al. (2018), the rivers of the region were important logistical pathways of agricultural products and raw materials derived from forest extraction in the 18th century. Currently, a large part of restoration actions of the basin follows the guidelines of the Atlantic Forest Restoration Pact (CALMON et al., 2009). One example of this are the actions of forest restoration in the Ecological Reserve of Guapiaçu (REGUA).

The refore objective of this work was to use the fluctuation of the sampled species in the families of termites: Kalotermitidae, Termitidae and Rhinotermeitidae, during the seasons of summer and winter of 2013 to 2015 , as a way of assessing the ecological quality of reforestation in that area.

\section{MATERIAL AND METHODS}

\section{Characterization of the Study Area}

The study area is located within the geographical limits of the 7380 ha of the Ecological Reserve of Guapiaçu - REGUA, between the coordinates UTM 23K 7287837515700 m N and M L. located in the rural community of Guapiaçu, the district of the municipality of Cachoeiras de Macacu, Rio de Janeiro State. It encompasses part of the Basin of the river Guapiaçu and block of forest remnants of the Serra do Mar. According to Köppen, the climate of the region is tropical with a rainy summer and a dry winter, classified as type AF. The work developed by Azevedo et al. (2018) on the same reservation determined the average annual temperature of $22.4^{\circ} \mathrm{C}$, with maximum in the months of January and February and minimum in June. The average annual rainfall is $2095 \mathrm{~mm}$, December and January are the wettest months and June and July the least rainy. During this study, the average temperature was $23.1^{\circ} \mathrm{C}$ and an average annual rainfall of 1307 $\mathrm{mm}$, July was the driest month with $32 \mathrm{~mm}$. The wettest month was December, with an average of $208 \mathrm{~mm}$.

Six sampling points were set in the basin of the River Guapiaçu (Figure 1). P01 was the closest to the area of pastures and agricultural crops; the reforestation has been happening in this area for approximately six years. P02 had great density of fruit species, with a focus on the attraction of ornithon and chiropteran fauna; the reforestation had been carried out in this area for eight years. P03 had the most recent reforestation area, that is, five years, fruit species and pioneers were found in this area. P04 is the area that has the highest density of pioneer species; in these area the deployment of fast-growing species as schinus terebinthifolia Raddi and Cecropia glaziovii Snethl was maximized; reforestation has been happening in this area for six years. P05 is the area in which it the methodological framework of the Atlantic Forest Restoration Pact (Calmon et al., 2009) was applied., it is an area with a high density of non- pioneer and climax species, arranged in rows of quincunx, the reforestation has been happening there for seven years. 


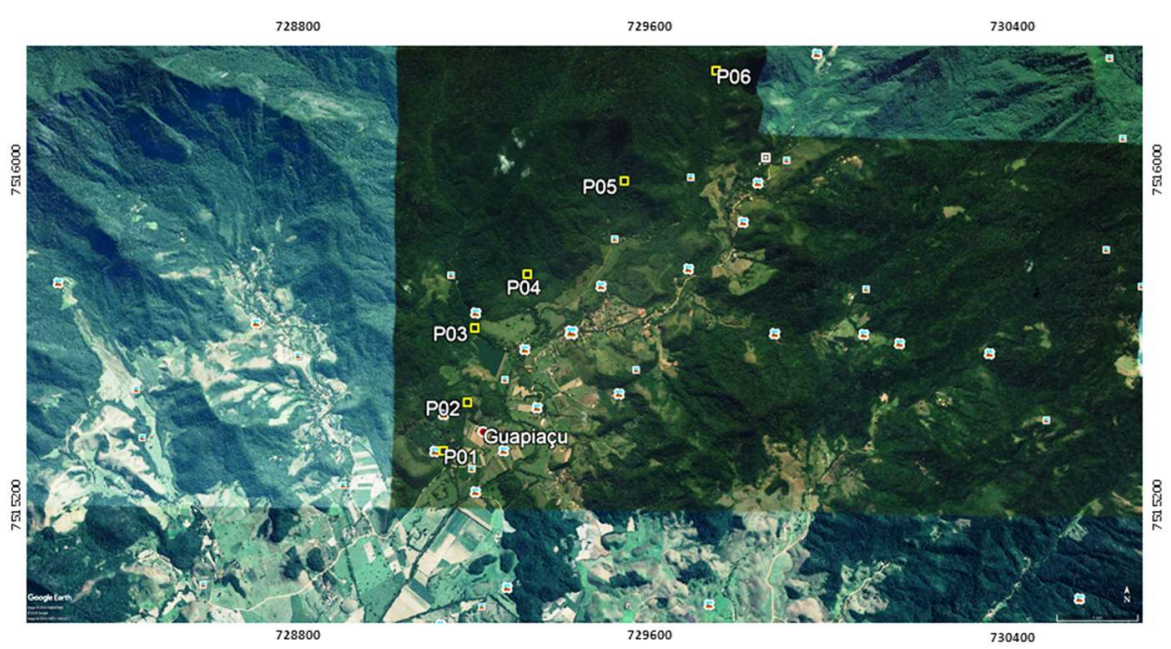

Figure 1: Sampling points in the Guapiaçu River basin. Source: by the author.

The control area is the P06, composed by those whose ecological characteristics are closer to the original not affected by anthropic pressure. Additionally, that is the area where access is the most difficult, the land with the highest topography.

For all sampling areas the history was the pasture for dozens of years, it is noteworthy that in P05, the perennation of a large body of water with lotic characteristics has been occurring, probably due to the reforestation.

\section{Sample Design and Analysis}

The protocol used to survey the richness of termite species was an adaptation of the sampling per quincunx. The quantitative samplings were marked in six transects, one at each sample point, at least $100 \mathrm{~m}$ apart from each other; each sub-parcel in five plots of $5 \times 2 \mathrm{~m}$, arranged on the left and the right, intermittently and with spacing of $10 \mathrm{~m}$ between them, for a total of 30 plots per locality. A distance of $250 \mathrm{~m}$ was kept from the edge of the forest, to avoid the "edge effects". The termites were searched in the soil, litter, under or inside of the fallen trunks, in dead trunks, under the bark of the trees up to a height of $1.5 \mathrm{~m}$, under rocks, in galleries, on the ground through holes of $15 \mathrm{~cm}$ and in the roots of grasses or shrubs, therefore, virtually in all micro-habitats where they could be found; the team took notes in codes for subsequent classification of species in trophic groups. As temporal scale pattern and sample effort, each plot was prospected during 1 hour/collector.

For the 3 years of collection, two annual collections were performed: one for the dry season of the year (winter) and another for the wet season of the year (summer). Always between $9 \mathrm{~h}$ and $17 \mathrm{~h}$. The total sampled area was $10,000 \mathrm{~m}^{2}$, for a sampling effort of $480 \mathrm{~h}$ per campaign. The termites collected were identified to the lowest taxonomic level possible and preserved in alcohol $70 \%$.

The guild food of termites was analyzed by direct observation in the field, in addition considering the data from the literature. The classification of the Termites in trophic groups was made according to the work of Eggleton et al., 1995: humivores or geofagos (termites that feed on organic particles of soil); intermediaries, known as "soil/wood interface-feeders" (termites that feed the soil/wood interface, were collected with the aid of tweezers, predominantly in the soil immediately beneath the fallen trunk or 
colonized them, or even inside of trunks in high stage of decomposition, where the soil is mixed with wood very degraded); Wood-eaters (termites that feed on dead wood); and the reapers or litter eaters (termites that cut sheets or feed on small pieces of wood and/or other items of litter). The termites collected were identified to the lowest taxonomic level possible and preserved in alcohol 70\%.

The bibliographical references of the works of descriptions of species mentioned here are in Constantino (1998). All the collected material was deposited in the zoological collection of the Laboratory of Environmental Mapping of UFRRJ (LAMAGEDENASA).

We plotted curves of accumulation of species for the six collection sites, and compared them to estimate the accumulated abundance of species per sample location and season in which occurred the collection. We analyzed the composition of species through multivariate models, to facilitate and enable the use of variables related to bioindicator species.

In regard to the number of specimens that were collected per campaign, because of the intrinsic characteristics of the group studied, we can hardly estimate it; since the statistics will be done by sampling effort, and not by the number obtained. The number of sampled insects varied and it was unlikely to be estimated for a site without a prior collection that informing the densities of the ecological community. We could have an estimate after the first year, but prior to it, it would be merely a guess. The sampling efforts in Ecological Entomology work with probabilistic comparisons of densities and frequencies, being the ' $n$ ' sampled, unlikely to be gauged to places never before sampled.

We analyzed the Ecological parameter Relative Frequency (RF), adapting it to the average number of seasons of collection, which is the percentage of the occurrence of the taxon $i$ by the sum of occurrences for all taxa of the component analyzed, where $\mathrm{FO}=(\mathrm{Oci} / \Sigma \times 100 \mathrm{OC})$, for the seasons of collection, the results found for the parameter frequency were essential for the creation of a table of evaluation of ecological quality, i.e., correlating the frequency of taxa with its auto-ecology.

Biological indexes should be sensitive to a range of biological impacts, not just narrow indicators, since the biological attributes chosen as measures must be capable of discriminating the impacts caused by man of variations from those of natural origin (temperature, speed of current) (Cristo et al., 2018). Therefore, the results were analyzed in a two-dimensional fashion, over time for each sampling point, and in a general way, with the aim of trying to discriminate against potential impacts on termite fauna. In this study, the communities were described according to the following indexes:

Shannon index $\left(\mathrm{H}^{\prime}\right)$ : The system of transects with subdivisions allows an indirect measure of abundance, through the number of encounters (frequency) in which the species was recorded in the plots (Brandão, 1998). The presence of species in a plot was defined as a meeting, and the total number of encounters per species treated as the measure of abundance. Thus, it was possible to calculate the diversity from the Shannon-Wiener index (logarithm in base 2). Calculated by $\mathrm{H}^{\prime}=\Sigma \mathrm{pi}^{*} \mathrm{Ln}(\mathrm{pi})$, where pi corresponds to the relative abundance of species $i$ (or ratio between the abundance of species $i$ and all individuals in the sample), and $\mathrm{Ln}$ is the natural logarithm. 
Pielou Evenness Index $\left(J^{\prime}\right)$ : It is derived from the diversity of Shännon index, which represents the uniformity of the distribution of individuals among the existing species apud. Its value has a range of 0 (minimum uniformity) to 1 (maximum uniformity). It is calculated by $\mathrm{J}^{\prime}=\mathrm{H}^{\prime} / \ln (\mathrm{S})$, where $\mathrm{N}$ corresponds to the richness of the sample and $H^{\prime}$ to the Shannon index of the same sample.

The multivariate analyses aim to reduce a large number of variables to a few dimensions with minimal loss of information, allowing the detection of main patterns of similarity and association between the sample units. With this purpose, we employed indirect ordination through the non-metric multidimensional scaling (MDS). The MDS is a sorting method that employs an iterative optimization algorithm to graphically represent (in one to three dimensions) the relations of similarity between the sample units. It differs from all other methods eigen (PCA, PCOA, CCA, etc.) by not assuming linear relationships between the variables and by better preservation of the relations of distances between the sampling units, often lost when reduced to orthogonal axes of greatest variation.

Stress is an index resulting from the analysis of MDS and represents the degree of adjustment of graphical distances between points to ecological distances between sample units. A stress $\leq 0.1$ corresponds to a good ordination.

In this study the chart MDS was elaborated from the bray-curtis similarity matrix, which in turn was derived based on data from seasonal abundance and frequency of each taxon raised by sampling unit. The Bray-Curtis index varies from 0 to 1 , with lower values indicating more similar samples. This standardization in the interval between one and zero facilitates the interpretation and comparison. For the preparation of analyzes, it was used the statistical software Past and the multiplatform spreadsheet open source software Calc, distributed for free with the suites OpenOffice.org and NeoOffice.

\section{RESULTS AND DISCUSSION}

The protocol proposed with sampling per quincunx, adapted for this study, proved to be adequate for the study of thermite biodiversity in this study. The results are similar to those of Bandeira et al. (1998), where a total of 43 taxons were collected in an area of 0.4 ha in the Buraquinho forest. In the same area, using the protocol ( $0.03 \mathrm{ha}$ ), which corresponds to only $7.5 \%$ of the sampled area, 38 species were found in the rainy season and 36 taxons in the dry season, corresponding to $88.3 \%$ and $83.7 \%$ of the total species found by Bandeira et al. (1998).

Four hundred and eleven occurrences of termites were recorded in the dry season of 2013 distributed in 30 taxons, for the wet season of this same year the record was of 420 occurrences also distributed in 30 taxons (Table 1).

For the dry season of 2014 there was an increase of 50 occurrences in relation to the year 2013, whence the peak record was of 461 occurrences, however, for a record of 28 taxons, i.e., two less than the previous one. As for the wet season of 2014, the record was of 467 occurrences distributed in 30 taxons. 
For the dry season of 2015 the record was of 478 occurrences distributed in 29 taxons, and for the wet season this year of 2015 the record was of 565 occurrences distributed in 30 taxons for this year in relation to the other was where you registered the largest number of occurrences.

However, the fluctuation in the number of species was 28 to 30 taxons, with a reduction of taxons for the dry season. The taxa that presented frequency of occurrence equal to 0 in some dry season of collection were: Atlantitermes sp. and Crepititermes verruculosus that are humivore and Convexitermes manni which is considered a reaper.

Table 1: Frequency of occurrence (FO \%) of the taxons of termites to all areas and seasons.

\begin{tabular}{|c|c|c|c|c|c|c|c|}
\hline \multirow[b]{2}{*}{ Taxa } & \multicolumn{2}{|c|}{2013} & \multicolumn{2}{|c|}{2014} & \multicolumn{2}{|c|}{2015} & \multirow[b]{2}{*}{ Food guild } \\
\hline & $\begin{array}{c}\text { Dry } \\
\text { season (\%) }\end{array}$ & $\begin{array}{c}\text { Wet } \\
\text { season (\%) }\end{array}$ & $\begin{array}{c}\text { Dry } \\
\text { season (\%) }\end{array}$ & $\begin{array}{c}\text { Wet } \\
\text { season (\%) }\end{array}$ & $\begin{array}{c}\text { Dry } \\
\text { season (\%) }\end{array}$ & $\begin{array}{c}\text { Wet } \\
\text { season (\%) }\end{array}$ & \\
\hline \multicolumn{8}{|l|}{ KALOTERMITIDAE } \\
\hline Cryptotermes brevis (Walker, 1853) & 4.08 & 4.26 & 4.17 & 3.85 & 3.68 & 4.23 & Wood-eater \\
\hline $\begin{array}{c}\text { Coptotermes gestroi (Wasmann, } \\
\text { 1896) }\end{array}$ & 4.08 & 4.26 & 4.17 & 3.85 & 3.68 & 4.23 & Wood-eater \\
\hline \multicolumn{8}{|l|}{ Calcaritermes rioensis (Krishna, } \\
\hline 1962) & 2.72 & 3.55 & 4.17 & 3.21 & 4.41 & 3.52 & Wood-eater \\
\hline Eucryptotermes sp. & 3.40 & 3.55 & 2.78 & 3.21 & 3.68 & 4.23 & Wood-eater \\
\hline Rugitermes Rugosus (Hagen, 1858) & 3.40 & 3.55 & 4.17 & 3.21 & 4.41 & 3.52 & Wood-eater \\
\hline \multicolumn{8}{|l|}{ RHINOTERMITIDAE } \\
\hline \multicolumn{8}{|l|}{ Heterotermes longiceps (Snyder, } \\
\hline 1924) & 2.72 & 2.84 & 3.47 & 3.85 & 4.41 & 4.23 & Wood-eater \\
\hline Dolichorhinotermes sp. & 2.04 & 2.13 & 2.78 & 1.92 & 4.41 & 2.82 & Wood-eater \\
\hline Heterotermes sp. & 3.40 & 3.55 & 3.47 & 2.56 & 2.94 & 3.52 & Wood-eater \\
\hline Rhinotermes sp. & 3.40 & 4.26 & 3.47 & 3.85 & 3.68 & 4.23 & Wood-eater \\
\hline \multicolumn{8}{|l|}{ TERMITIDAE } \\
\hline \multicolumn{8}{|l|}{ Apicotermitinae } \\
\hline Anoplotermes sp. 1 & 2.04 & 2.13 & 2.78 & 3.21 & 2.21 & 2.11 & Humivore \\
\hline Anoplotermes sp. 2 & 3.40 & 2.13 & 3.47 & 1.92 & 2.21 & 3.52 & Humivore \\
\hline Tetimatermes sp. & 3.40 & 2.84 & 2.78 & 1.92 & 2.94 & 1.41 & Humivore \\
\hline Nasutitermitinae & & & & & & & \\
\hline \multicolumn{8}{|l|}{ Angularitermes pinocchio (Cancello } \\
\hline et. al., 1996) & 4.08 & 3.55 & 4.17 & 3.85 & 2.94 & 2.82 & Humivore \\
\hline Agnathotermes sp. & 4.08 & 4.26 & 3.47 & 3.85 & 2.21 & 2.82 & Humivore \\
\hline Araujotermes sp. & 3.40 & 4.26 & 3.47 & 3.85 & 3.68 & 2.82 & Humivore \\
\hline Atlantitermes sp. & 0.68 & 2.13 & 0.00 & 3.21 & 1.47 & 4.23 & Humivore \\
\hline \multicolumn{8}{|l|}{ Armitermes euamignathus (Silvestri, } \\
\hline 1901) & 4.08 & 3.55 & 4.17 & 3.85 & 3.68 & 4.23 & Wood-eater \\
\hline \multicolumn{8}{|l|}{ Convexitermes manni (Emerson, } \\
\hline 1925) & 1.36 & 2.13 & 0.00 & 3.21 & 0.74 & 2.11 & Intermediary \\
\hline \multicolumn{8}{|l|}{ Embiratermes neotenicus } \\
\hline (Holmgren, 1906) & 2.04 & 2.13 & 2.08 & 3.85 & 2.21 & 3.52 & Intermediary \\
\hline \multicolumn{8}{|l|}{ Labiotermes labrali (Holmgren, } \\
\hline 1906) & 4.08 & 3.55 & 4.17 & 3.85 & 4.41 & 2.11 & Humivore \\
\hline \multicolumn{8}{|l|}{ Nasutitermes ephratae (Holmgren, } \\
\hline 1910) & 4.08 & 3.55 & 4.17 & 2.56 & 2.94 & 2.11 & Wood-eater \\
\hline \multicolumn{8}{|l|}{ Nasutitermes callimorphus } \\
\hline (Mathews, 1997) & 4.08 & 4.26 & 4.17 & 3.21 & 4.41 & 3.52 & Wood-eater \\
\hline \multicolumn{8}{|l|}{ Nasutitermes corniger } \\
\hline (Motschulsky, 1855) & 4.08 & 4.26 & 4.17 & 3.85 & 4.41 & 2.82 & Wood-eater \\
\hline \multicolumn{8}{|l|}{ Nasutitermes macrocephalus } \\
\hline (Silvestri, 1903) & 4.08 & 4.26 & 3.47 & 3.85 & 3.68 & 3.52 & Wood-eater \\
\hline Nasutitermes minor (Holmgren, & & & & & & & \\
\hline 1906) & 3.40 & 4.26 & 3.47 & 3.85 & 4.41 & 4.23 & Wood-eater \\
\hline Subulitermes sp. & 4.08 & 2.84 & 3.47 & 3.21 & 3.68 & 4.23 & Humivore \\
\hline Velocitermes sn & & & & & & & Ebonblade \\
\hline ocitermes sp. & 4.08 & 3.55 & 4.17 & 3.21 & 3.68 & 2.82 & Reaper \\
\hline Termitinae & & & & & & & \\
\hline Amitermes amifer (Silvestri, 1901) & 4.08 & 4.26 & 4.17 & 3.85 & 4.41 & 4.23 & Wood-eater \\
\hline
\end{tabular}


Microcerotermes exiguus (Hagen,

1858)

Crepititermes verruculosus

(Emerson, 1925)
2.72

3.40
3.55

0.71
2.78

2.78
3.85

2.56
4.41

0.00
4.23

2.11
Humivore

The termite colonies of dry wood, according to Constantino (2002), belong to the Kalotermitidae family and infest dry wood, non rotted, structural, furniture, branches of live trees in a shady spot, trees in orchards, posts and stored wood. In Brazil most species of this family are exotic and of commercial importance, due to their synanthropic behavior.

In areas P01, P02 and P03, there was a high frequency of Coptotermes gestroi, an exotic species and xylophage common and of great economic importance in the urban and peri-urban regions, where it is one of the most frequent urban plagues (Bandeira et al., 2003). According to Constantino (2002), Coptotermes gestroi is one of the most important pest species in South America. Like almost any pest species, it presents a certain plasticity, including nests, which may be polygalic, increasing the foraging foraging area of each colony. Bandeira et al. (2003) report that this species was not recorded in primary forest and was the most frequent in areas where there was some type of disturbance. The P05 area presented very low occurrence of this species and the P06 area had no occurrence.

The subfamily Apicotermitinae (Termitidae) currently represents the greatest taxonomic challenge of Blattodea (Constantini et al., 2018). The neotropical representatives of the subfamily (genre Anoplotermes) do not present the caste of the soldiers, the most used for taxonomic identification, which raises the importance of the characters of the digestive tube of workers to identify the species. The reduced number of species and the low frequency of termite encounters of the subfamily Apicotermitinae and the food group of the humivores apparently are related to the antropic presence, only in the areas P05 and P06 there were frequencies of this family, in the other areas where the presence of human dwellings and a high frequency of termitas of dry wood were evidenced, this family was not frequent.

The behavior of the Shannon index $\left(\mathrm{H}^{\prime}\right)$ was of consistent increase for the humid campaigns in relation to the dry campaigns, a fact that is due to the higher density of humivore and reaper termites during the wet season. The Pielou Evenness $\left(J^{\prime}\right)$, with the exception of the dry season of 2013, presented a homogeneous distribution of species for all areas. The Pielou Evenness of the dry season of 2013 may have a relation with a possible dominance of wood-eating termites recorded in this year's seasonal period (Figure 2C).

Regarding the behavior of the curve of the manifold (Figure 3F), the only sample area in which there was not a stabilization of accumulated richness of taxons was the control area P06, all other 5 areas presented curve stabilization, indicating that the sampling were sufficient for these sample areas. The areas P01 and P02 showed a level of 28 taxons and the areas P03, P04 and P05 showed a level of 27 taxons.

The areas that presented a higher level of wood consumption were P04 and P03. However, P05 presents more similar values to the control area P06. Incidentally, that was the only sample area in which the percentage of humivores was greater than $40 \%$, similar to the control area P06, thus highlighting its 
successful reforestation process attributed to the methodological framework the Atlantic Forest Restoration

Pact (Table 2).

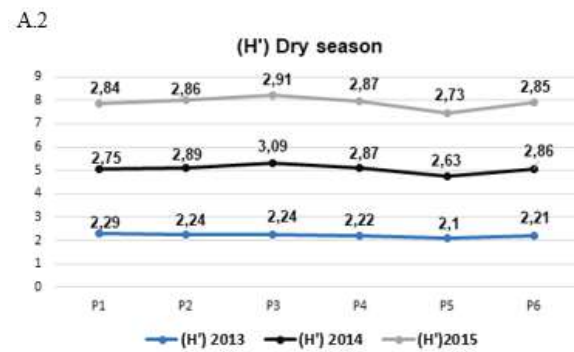

C. 2

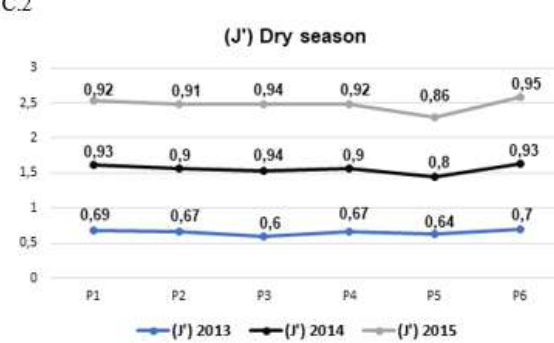

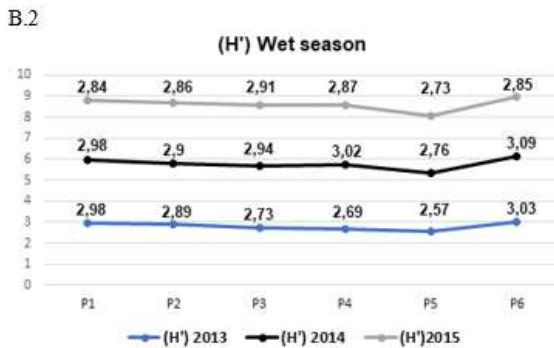

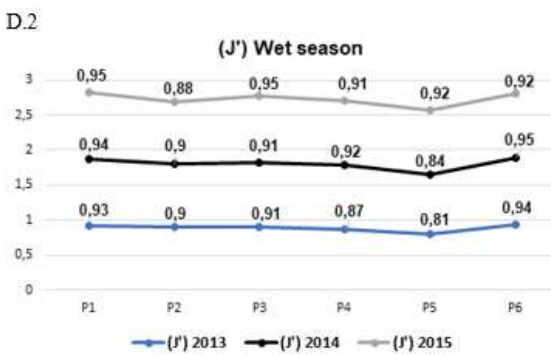

Figure 2: Shannon index $\left(\mathrm{H}^{\prime}\right)$ and Pielou evenness $\left(\mathrm{J}^{\prime}\right)$ for all sampling areas and seasons.

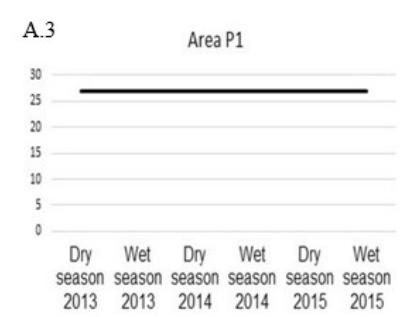

D.3

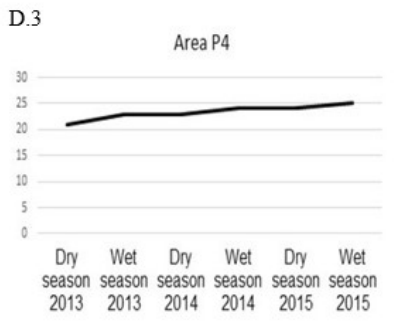

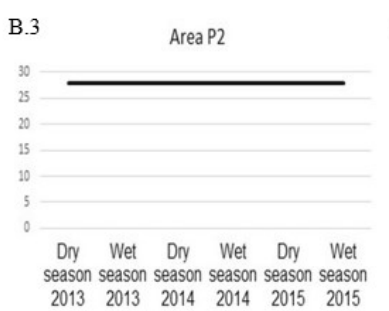

E.3

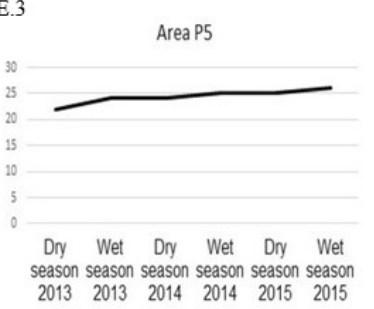

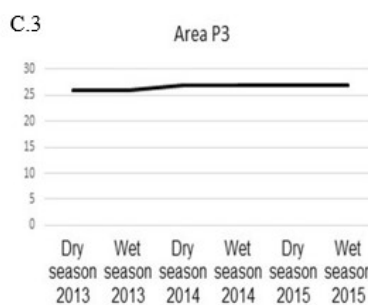

F.3

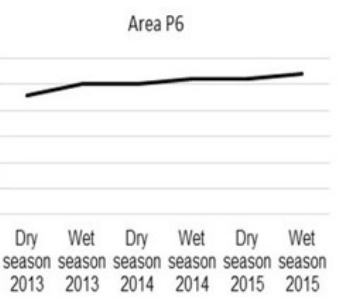

Figure 3: Accumulated wealth of species for the six sampling areas and collection stations.

Table 2: Frequency of occurrence (FO\%) as the food guild, by area of study. Note: In bold are the areas with high gradient of Wood-eaters ( $>60 \%)$ and with high gradients of humivores $(>40 \%)$.

\begin{tabular}{|c|c|c|c|c|c|c|}
\hline \multicolumn{7}{|c|}{ Guild food to dry Campaign 2013} \\
\hline & P01 (\%) & P02 (\%) & P03 (\%) & P04 (\%) & P05 (\%) & P06 (\%) \\
\hline Wood-eater & 61.54 & 57.69 & 66.67 & 54.17 & 54.17 & 42.86 \\
\hline Humivore & 26.92 & 34.62 & 29.17 & 37.50 & 41.67 & 47.62 \\
\hline Ebonblade Reaper & 3.85 & 3.85 & 4.17 & 4.17 & 4.17 & 4.76 \\
\hline Intermediary & 7.69 & 3.85 & 0.00 & 4.17 & 0.00 & 4.76 \\
\hline \multicolumn{7}{|c|}{ Food guild for wet Campaign 2013} \\
\hline & P01 (\%) & P02 (\%) & P03 (\%) & P04 (\%) & P05 (\%) & P06 (\%) \\
\hline Wood-eater & 58.33 & 64 & 80 & 66.67 & 58.33 & 44 \\
\hline Humivore & 33.33 & 24 & 20 & 23.81 & 37.50 & 44 \\
\hline Ebonblade Reaper & 4.17 & 4 & 0.00 & 4.76 & 4.17 & 4 \\
\hline Intermediary & 4.17 & 8 & 0.00 & 4.76 & 0.00 & 8 \\
\hline \multicolumn{7}{|c|}{ Guild food to dry Campaign 2014} \\
\hline & P01 (\%) & P02 (\%) & P03 (\%) & P04 (\%) & P05 (\%) & P06 (\%) \\
\hline Wood-eater & 75 & 53.85 & 59.26 & 66.67 & 55.56 & 50.00 \\
\hline Humivore & 15 & 38.46 & 37.04 & 25.00 & 37.04 & 45.45 \\
\hline
\end{tabular}




\begin{tabular}{|c|c|c|c|c|c|c|}
\hline Ebonblade Reaper & 5 & 3.85 & 3.70 & 4.17 & 3.70 & 4.55 \\
\hline Intermediary & 5 & 3.85 & 0.00 & 4.17 & 3.70 & 0.00 \\
\hline \multicolumn{7}{|c|}{ Food guild for wet Campaign 2014} \\
\hline & P01 (\%) & P02 (\%) & P03 (\%) & P04 (\%) & P05 (\%) & P06 (\%) \\
\hline Wood-eater & 58.33 & 64 & 60 & 51.85 & 48.15 & 46.15 \\
\hline Humivore & 29.17 & 24 & 36 & 37.04 & 40.74 & 42.31 \\
\hline Ebonblade Reaper & 4.17 & 4 & 0 & 3.70 & 3.70 & 3.85 \\
\hline Intermediary & 8.33 & 8 & 4 & 7.41 & 7.41 & 7.69 \\
\hline \multicolumn{7}{|c|}{ Guild food to dry Campaign 2015} \\
\hline & P01 (\%) & P02 (\%) & P03 (\%) & P04 (\%) & P05 (\%) & P06 (\%) \\
\hline Wood-eater & 72.73 & 60.87 & 68.18 & 69.57 & 58.33 & 55 \\
\hline Humivore & 22.73 & 26.09 & 27.27 & 21.74 & 33.33 & 45 \\
\hline Ebonblade Reaper & 4.55 & 4.35 & 4.55 & 4.35 & 4.17 & 0.00 \\
\hline Intermediary & 0.00 & 8.70 & 0.00 & 4.35 & 4.17 & 0.00 \\
\hline \multicolumn{7}{|c|}{ Food guild for wet Campaign 2015} \\
\hline & P01 (\%) & P02 (\%) & P03 (\%) & P04 (\%) & P05 (\%) & P06 (\%) \\
\hline Wood-eater & 59.09 & 65.22 & 76.19 & 56.52 & 50 & 51.85 \\
\hline Humivore & 31.82 & 21.74 & 23.81 & 34.78 & 38.46 & 40.74 \\
\hline Ebonblade Reaper & 4.55 & 4.35 & 0.00 & 4.35 & 3.85 & 0.00 \\
\hline Intermediary & 4.55 & 8.70 & 0.00 & 4.35 & 7.69 & 7.41 \\
\hline
\end{tabular}

For the species of humivorous termites, intermediates and Ebonblade Reaper, the content of silt, clay, organic matter and soil clay activity, as well as the organic matter content of the litter and the phytophysiognomy itself affect the richness of these species, Finally, the less anthropic areas presented higher frequency of these guilds.

Regarding the abundance and frequency of species, the similarity synthesized by the multivariate method of non-metric multidimensional scaling (Figure 4), indicated that the sample area that has greater similarity with the control area P06 was the P05. The areas P01 and P03, which showed the highest frequency of wood-eating termites, also demonstrated some similarity. Multivariate analysis opposed the frequency of occurrence for the guilds food.

Areas of clearings and edges are determinants to the population growth of wood-eater and reaper termites (Reis et al., 2009). Moreover, larger amounts of litter and stabilization of the organic matter favors the humivores and intermediaries (Rocha et al., 2012). Thus, it was understood that the area P05 which has a higher density of non-pioneer forest species and planted in rows of quincunx, create environments more similar to natural areas with high levels of preservation, providing a greater similarity with the control area P06.

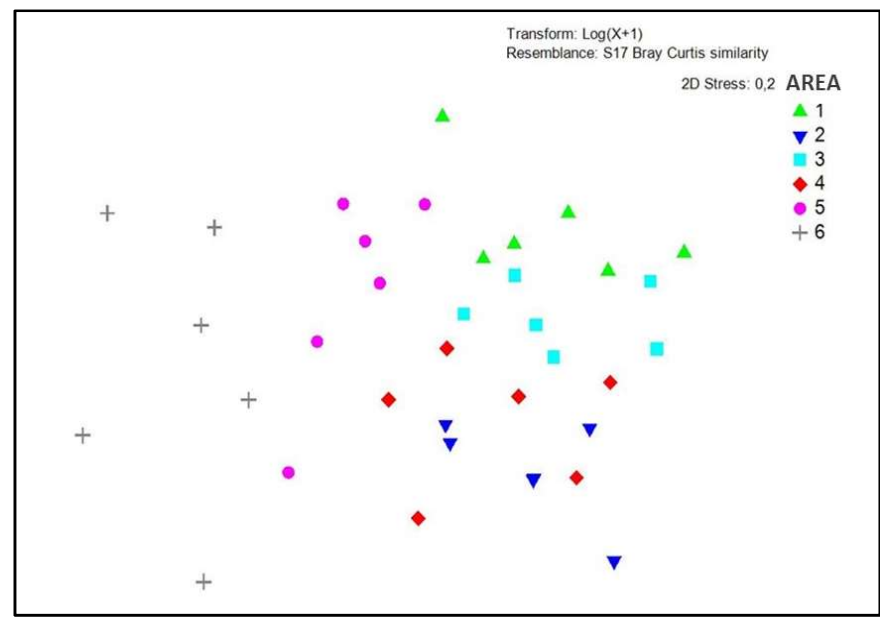

Figure 4: Graph of non-metric multidimensional analysis (MDS) drawn from the bray-curtis similarity matrix, on the basis frequency of occurrence (FO\%) and the abundance of species of termites. 
The Atlantic Forest is a hot spot of biodiversity, many are the actions of forest restoration carried out in their ecosystems, therefore a biome of priority to conservation and environmental preservation, the recovery of degraded areas becomes relevant to have the proper provision of environmental services, however the methodologies deployed in this restoration must be reassessed, since this study indicated that the large deployment of pioneer species may compromise the ecological health of their ecosystems.

\section{CONCLUSIONS}

Compared to other surveys following protocols similar to the use of quincunx, this work has proved to be relevant to the use of termites as environmental assessment tools.

The correct choice of the proportion of climactic and pioneer forest species in a reforestation were shown to be of great importance and influence in the community of termites that will colonize the referred forest ecosystem, in such a way that more diverse reforestations and with the presence of climactic species presented their wealth more influenced for humivore termites, intermediates and Ebonblade Reaper. On the other hand, reforestations with a greater diversity of pioneer forest species showed its richness influenced by dry wood-eater termites.

The presence of exotic species of the Kalotermitidae family in high density areas of pioneer species demonstrates how important the selection of climactic species in reforestation is, and deserved to be warned and pointed out that this family of termite is found in the Atlantic Forest.

For the seasons of collection, the results found for the parameter frequency were essential for the creation of a table of evaluation of ecological quality, which can be used in forest restoration activities in the Mata Atlântica biome, which is totally unheard of and may still be a reference for other biomes.

New species can be raised, Further studies are still needed, such as the structure of the jaws and the digestive tract of workers of many species, the contents of the tube digestive system of the workers and, especially, careful and direct observations in the field, so that the diet of individuals of many species can be confirmed.

\section{REFERÊNCIAS}

AZEVEDO, A. D.; CAMARA, R.; FRANCELINO, M. R.; PEREIRA, M. G. G.; LELES, P. S. S.. Estoque de Carbono em Áreas de Restauração Florestal da Mata Atlântica. Floresta (Online) (Curitiba), v.48, p.183, 2018. DOI:

http://dx.doi.org/10.5380/rf.v48i2.54447

BANDEIRA, A. G.; PEREIRA, J. C. D.; MIRANDA, Y. C. S. \& MEDEIROS, L. G. S.. Composição da fauna de térmitas (Insecta: Isoptera) em áreas de Mata Atlântica em João Pessoa, Paraíba, Brasil. Revista Nordestina de Biologia, v.12, n.1-2, p.9-17, 2018.

BRANDÃO, D.. Patterns of the termite (Isoptera) diversity in the Reserva Florestal de Linhares, State of Espírito Santo, Brazil. Revista Brasileira de Entomologia, v.41, n.2-4, p.151153, 1998.
CABRERA DÁVILLA, G.; CANCELLO, E. M.. Termitas (Insecta: Isoptera) de Topes de Collantes, provincia de Sancti Spíritus, Cuba central. Boletín de la SEA, v.44, p.567-568, 2009.

CALMON, M.. Pacto pela restauração da Mata Atlântica: um movimento pela restauração da floresta. Fujihara, M. A.. O valor das florestas. São Paulo: Terra das Artes, 2009.

CONSTANTINO, R.. Abundance and diversity of Termite (Insecta: Isoptera) in two sites of primary rain forest in Brazilian Amazonia. Biotropica, v.24, n.3, p.420-430, 1992. DOI: http://dx.doi.org/10.2307/2388611

CONSTANTINO, R.. Catalog $f$ the living termites of the New World (Insect: Isoptera). Arquivos de Zoologia, v.35, p.135260, 1998. DOI: https://doi.org/10.11606/issn.21767793.v35i2p135-230 
CONSTANTINO, R.. The pest termites of South America: taxonomy, distribution and status. Journal of Applied Entomology, v.126, p.355-365, 2002. DOI: https://doi.org/10.1046/j.1439-0418.2002.00670.x

CONSTANTINI, J. P.; CARRIJO, T. F.; PALMA-ONETTO, V.; SCHEFFRAHN, R.; CARNOHAN, L. P.; SOBOTNIK, J.;

CANCELLO, E. M.. Tonsuritermes, a new soldierless termite genus and two new species from South America (Blattaria: Isoptera: Termitidae: Apicotermitinae). Zootaxa, v.4531, n.3, p.383-394, 2018. DOI:

http://dx.doi.org/10.11646/zootaxa.4531.3.4

CRISTO, S. C.; VITORINO, M. D.; CARVALHO, A. G.. Leaf-litter entomofauna as a parameter to evaluate areas under ecological restoration. FLORAM, 2018. DOI: https://doi.org/10.1590/2179-8087.029517

EGGLETON, P.; BIGNEL, D. E.; SANDS, W. A.; WAITE, B.; WOOD, T. G.; LAWTON, J. H.. The species richness (Isoptera) under differing levels of forest disturbance in the Mbalmayo Forest Reserve, southern Camerron. Journal of Tropical Ecology, v.11, p.85-98,1995. DOI: https://doi.org/10.1017/S0266467400008439
KRISHNA, K.; GRIMALDI, D. A.; KRISHNA, V.; ENGEL, M. S.. Treatise on the Isoptera of the world: 1. Introduction. Bulletin of the American Museum of Natural History, v.377, n.1, p.1-200, 2013

KRISHNA, K.; GRIMALDI, D. A.; KRISHNA, V.; ENGEL, M. S.. Treatise on the Isoptera of the world: 5 Termitidae (part two). Bulletin of the American Museum of Natural History v.377, n.5, p.1499-1987, 2013.

REIS, Y. T.; DELABIE, J.; CANCELLO, E. M.. Térmites (Insecta: Isoptera) da Reserva Zoobotânica do Centro de Pesquisa do Cacau, Ilhéus, Bahia, Brasil. Agrotrópica (Itabuna), v.21, p.103-108, 2009.

ROCHA, M.; CANCELLO, E. M. ; CARRIJO, T. F.. Neotropical termites: revision of Armitermes Wasmann (Isoptera, Termitidae, Syntermitinae) and phylogeny of the Syntermitinae. Systematic Entomology, v.37, p.793-827, 2012. DOI: https://doi.org/10.1111/j.13653113.2012.00645.x

A CBPC - Companhia Brasileira de Produção Científica (CNPJ: 11.221.422/0001-03) detém os direitos materiais desta publicação. Os direitos referem-se à publicação do trabalho em qualquer parte do mundo, incluindo os direitos às renovações, expansões e disseminações da contribuição, bem como outros direitos subsidiários. Todos os trabalhos publicados eletronicamente poderão posteriormente ser publicados em coletâneas impressas sob coordenação da Cognitionis Publishing, da Companhia Brasileira de Produção Científica e seus parceiros autorizados. Os (as) autores (as) preservam os direitos autorais, mas não têm permissão para a publicação da contribuição em outro meio, impresso ou digital, em português ou em tradução. 